\title{
IMPLICATURES IN FOURTH GRADE STUDENTS' BOOKS OF THE 2013 CURRICULUM REVISION EDITION AT 2016
}

\author{
Ni Komang Arini ${ }^{1}$, I Nyoman Suparwa ${ }^{2}$, Made Sri Satyawati ${ }^{3}$ \\ arie.komang24@gmail.com \\ Udayana University, Denpasar 80114, Indonesia
}

\begin{abstract}
This study is focused on implicatures in fourth grade students' books of the 2013 curriculum revision edition at 2016. It aimed at identifying the forms of implicatures and the background contexts which were found in the students' books of the 2013 curriculum theme 6 and theme 9 for the fourth grade of elementary school. This study used implicature theory based on Grice's perspective which distinguished implicatures based on their types, namely conventional implicatures, and unconventional implicatures. In addition, this study also examined the conventional implicatures and conversational implicatures that arise as a result of speakers not obeying the maxims in the principle of cooperation and the maxims contained in the principle of politeness. References to other theories were the context of speech situations and the context of language use. The method used was a qualitative descriptive method. The data collected was in the form of words or written speech. The data was obtained from the fourth-grade elementary school students' book of the 2013 curriculum revised edition in 2016 in two integrated thematic books, namely, theme 6 (Cita-citaku) and theme 9 (Kayanya Negeriku).The results showed that the implicatures found in the sixth and ninth theme students' books were conventional implicatures and non-conventional implicatures. In the student book theme 6 , there were 7 conversational implicatures found and in the student book theme 9 found 8 conversational implicatures. Besides that, the researcher also found 4 conventional implicatures in the students' book theme 6 and 8 other conventional implicatures in the students' book theme 9 . The maxims that were violated based on the principle of cooperation were the maxim of quantity, the maxim of quality, and the maxim of relevance. Besides that, the context behind the speech event was in the form of background knowledge that is both understood by the speakers and their speech partners. The context of the purpose of the speech that was found is entirely influenced by the themes proclaimed in each book.
\end{abstract}

Published by IJRP.ORG. Selection and/or peer-review under responsibility of International Journal of Research Publications (IJRP.ORG)

Keywords: Implicatures, Students' Book, Curriculum 2013

\section{Introduction}

In essence, language is something that is individual because the sounds of language are produced by individual speakers. Richard \& Schmidt (2010: 311) also state that language is a communication system consisting of structured sound arrangements into larger units. Thus, language has an important role in human life to interact with each other because by its nature, language is a free sound symbol used by community 
members to work together or relate (Dhanawati, et al., 2017: 4). Therefore, language is used as a tool to express everything that is implied in the thoughts and feelings of the speaker. Expression of human thoughts and feelings is influenced by two things, namely by the state of mind and feeling itself. Expression of spoken language can be seen from the expression, song/intonation, stress, and others. Expression of written language can be seen by diction, use of punctuation marks, and language style.

However, usually, not many people have a problem with how language can be used as an effective medium of communication, so as a result speakers of a language often experience misunderstandings in the atmosphere and context of their speech. One way to find out about it is through a pragmatic point of view. Pragmatics refers to the study of language use based on context. The fields of study related to this, which are then commonly called the field of pragmatic studies, are deixis, presuppositions, speech acts, and conversational implicatures. Implicature is information that has additional meaning than just words (Yule, 1996: 61). The term implicature arises based on the phenomenon that in speech, speakers and speech partners are advised to obey the principles of conversation. However, the participants in the speech, intentionally or not, may violate the principle of the conversation.

In this case, the use of implicatures in a conversation often makes the speech partner does not understand the meaning of the speech so that the speech partner often ignores the speech conveyed by the speaker. The difference between speech and message (implication) that the speaker wants to convey sometimes makes it difficult for the speaker to understand it. As previously mentioned, implicatures can be caused by violating the principle of conversation or as appears in communication between characters in the fourth-grade elementary school student book of 2013 curriculum. Therefore, the author is interested in conducting research with its aims to identify the implicatures and the background context in an integrated thematic book of the 2013 curriculum for fourth-grade elementary school students.

\section{Theoretical Framework}

\subsection{Implicatures}

The term implicature is derived from the verb to imply which means stating something indirectly. Etymologically, to imply means to wrap or hide something by using something else. Therefore, conversational implicature is something that is hidden in a conversation, that is, something that is implicit in the actual use of language. Brown and Yule (1996: 31) state that implicature is used to explain what the speaker might mean, suggest, or mean as different from what the speaker actually said. In other words, it can be explained that implicature is one part of pragmatic studies in addition to deixis, presuppositions, speech act, and aspects of discourse structure. Implicature means something that is implied.

In order to understand what a speaker means, the interlocutor must always interpret his/her utterances. Grice (1975) explains that there are two kinds of implicatures, namely conventional implicatures and conversational implicatures. Yule (1996: 70-74) states that there are three types of conversational implicatures, namely specific conversational implicatures, general conversational implicatures, and scaled conversational implicatures.

Thus, the conversational implicature is a part of pragmatic studies that specializes in the study of an implicit meaning of a conversation that is different from the literal meaning of a conversation. To further clarify the understanding of this implicature, the following will be presented four characteristics of implicature according to Nababan (1987:39) as follows:

1. A conversational implicature can be canceled in certain cases, for example by adding a clause saying that someone does not want to use the conversational implicature, or providing a context to cancel the implicature.

2. Usually there is no other way to say what was said and still retain the pertinent implicature. 
3. Conversational implicatures require prior knowledge of the conventional meaning of the sentences used. Therefore, the contents of the conversational implicature are not included in the meaning of the sentence used.

4. The truth of the contents of a conversational implicature does not depend on the truth that is said. Therefore, implicature is not based on what is said, but on the action that says it.

In line with that, the implicature is a prime example of more information being conveyed than is said so that implicatures can be interpreted some basic cooperative principles must be assumed early in their implementation.

\subsection{Cooperative Principle}

In normal communication, it can be assumed that the speaker articulates the utterance and the intention to produce something for his interlocutor, and hopes that the speech partner can understand what he/she wants to communicate. For this reason, the speaker tries to make his speech always clear, concise, always on the subject, and easily understood by his interlocutor (Wijana, 1996: 45).

Grice as quoted in Nugraheni (2010) connects the concept of conversational implicatures with the principles of cooperation. The concept of the principle of cooperation basically regulates what participants must do so that the speech runs smoothly. Meanwhile, conversational implicatures arise due to the violation of the principle of cooperation. The principle of cooperation that is violated and becomes a source of conversational implicatures consists of four maxims (Wijana, 1996: 46), as follows;

1. Maxim of Quantity

This maxim expects the speech participant to give a response or answer that is sufficient or as much as needed by the interlocutor. For example, if someone is asked what his/her name is, then he/she does not need to provide any other answers other than information about his/her name, such as an address, status, and so on.

2. Maxim of Quality

This conversational maxim requires that each participant of the communication tells the truth. This means that the answer or response should be based on sufficient evidence.

3. Maxim of Relevance

This maxim requires each participant to make a relevant contribution to the topic of conversation. The maxim of relevance emphasizes the relationship between the speech content of the speech participants. Each participant of the conversation contributes to each other that is relevant to the topic of conversation so that the topic of conversation can be reached effectively.

However, sometimes the explicit response given does not appear relevant to the subject because there is already become a common background knowledge between the speaker and the interlocutor so that communication is still ongoing. In other words, it seems explicitly irrelevant but is actually implicitly relevant.

4. Maxim of Manner

This maxim requires each participant of the conversation to speak directly, not vague, not taxa, coherently, and not excessively. When this is violated, the speaker usually has a specific purpose, for example, to deceive or create a funny effect. It contains the goal that speakers contribute information clearly, namely contributions that avoid ambiguity and ambiguity. Thus, the speaker's contribution must be short, clear, and orderly.

The principle of cooperation according to Leech (1993) is needed to make it easier to explain the relationship between meaning and power; such an explanation is very adequate, especially for solving problems that arise in semantics using a truth-based approach. But the cooperative principle itself cannot explain why humans often use indirect means to convey what they mean; and what is the relationship between meaning and power in non-declarative sentences. So, this is where the role of politeness becomes important. 

principle of cooperation, or prioritize one maxims of the principle of politeness over the other.

\subsection{Politeness Principle}

Politeness is the treatment of a firm concept related to polite social behavior found in a culture or a society. Especially in language, language etiquette is respect. Politeness in the language is manifested through clarity and brevity of word usage. In line with that what is meant by clarity is conveying something clearly or effectively in all aspects such as word structure in sentences, correspondence with revealed facts, logical arrangement, the use of speech figures, and comparisons. The point is to convey something concisely and efficiently, eliminating loosely synonymous words and avoiding unnecessary repetition.

In social interactions in a culture, it is necessary to show wise, generous (smile), humble and sympathetic traits to others. Technically, in facial interactions or facial features, it is a person's personal form in society. Facial romance refers to a person's social and emotional meaning when dealing with other people. The principle of politeness has several maxims, namely the tact maxim, the generosity maxim, the appropriation maxim, the modesty maxim, the agreement maxim, and the maxim of sympathy (Wijana,1996). The principle of politeness relates to two speakers in dialogue.

1. The Tact Maxim

This maxim outlines each participant in the speech to minimize the loss of others or maximize the benefits of others. In this case, Leech (in Wijana, 1996) says that the longer a person's speech, the greater the person's desire to be polite to the interlocutor. Likewise, indirect speech is usually more polite than directly expressed utterances. In relation to Based on the level of politeness, the longer the speech given by the speaker, the more polite a person is in speaking.

2. The Generosity Maxim

The maxim of generosity demands that each participant of the speech maximize respect for others, and minimize disrespect for others.

3. The Appropriation Maxim

The maxim of acceptance is expressed in commissive and impositive sentences. This maxim requires each participant of the speech act to maximize the loss for himself, and minimize his own gain.

4. The Modesty Maxim

The humility maxim is self-centered. This maxim requires each participant of the speech to maximize self-disrespect, and minimize self-respect.

5. The Agreement Maxim

The maxim of compatibility outlines each speaker and interlocutor to maximize the match between them, and minimize the mismatch between them.

6. The Maxim of Sympathy

This maxim is expressed in assertive and expressive speech. The sympathy maxim requires each participant of the speech to maximize sympathy and minimize antipathy to the interlocutor.

\subsection{Context}

Context can be said to be everything in communication so that the meaning interpreted by the interlocutor is parallel or the same as the intent conveyed by the speaker (Haliko, 2017). Context is the aspects of the physical or social environment that are related to certain utterances. The idea of context is beyond its obvious manifestation, such as the physical setting in which an utterance is produced, which includes linguistic and social factors (Cummings, 2007: 5). The context of the situation is very influential in interpreting a word, sentence spoken by the speaker. In the context of situations, the meanings of words can change according to environmental stress, tone of speech, circumstances that occur, and so on. In addition, Leech (in Haryono, 2010: 10) suggests that context is defined as aspects that are related to the physical and social environment as 
interpret the meaning of speech.

Jumanto (2006: 31) states that the context in pragmatics is; (a). a dynamic concept and must be understood as an environment or series of world realities that are constantly changing, and what backgrounds are known to the speaker and speech partner so that a communicative communication process occurs, (b). context includes textual references (context) and situational references, and (c). Context is used to understand all the factors that play a role in producing and understanding speech and is oriented to the user. In relation to the context of the speech situation, Wijana (in Haryono 2010: 11) suggests that the context in question includes the following aspects; the speaker and the interlocutor, the context of the speech, the purpose of the speech, the goal as a form of action or activity, speech as a product of verbal acts.

\section{Methods}

The research design was a descriptive qualitative research. In conducting this research, the finding and describing phonetically were focused on the pronunciation errors of English segmental acquired and the factors caused the errors. Data collection used to gather and collect data. In this step, gathering and collecting data were the documentation from the two themes of students' books in order to answer the research questions formulated.

\section{Result and discussion}

Based on the research data, it was found that there were two types of implicatures contained in student books, namely conventional implicatures, and non-conventional implicatures. The data in the results of this study were based on Grice's theory (1975) which explains that implicature consists of two types, namely conventional implicature, and non-conversational implicature. Further explanation of the two implicatures is then discussed respectively, as follows.

\subsection{The Nonconventional Implicature}

Implicature is a prime example of more information being conveyed than said so that implicatures can be interpreted, some basic cooperative principles must be assumed in their implementation (Yule, 1996). Based on the research data in the student's book as the object of research, it was found that there were several conversational implicatures that arise due to the violation of the maxim of quality, the maxim of quantity and the maxim of relevance in the principle of cooperation. The maxims based on the cooperative principle are violated by speakers because they prioritize the maxims contained in the politeness principle. Therefore, the sample of nonconventional implicature was then presented bellow was found in the book theme 6 on page 6 ;

Udin : Benarkah? Apa cita-citamu, Lani?

Lani : "Aku senang dengan hewan. Aku ingin suatu hari nanti bisa menjadi dokter hewan agar aku dapat membantu hewan-hewan yang sakit dan butuh pertolongan."

The context of the conversation above between Udin and Lani discusses Lani's aspirations to become a veterinarian. The implicature contained in the conversation fragment above occurs because of the violation of the maxim of quantity in Lina's speech "Aku senang dengan hewan. Aku ingin suatu hari nanti bisa menjadi dokter hewan agar aku dapat membantu hewan-hewan yang sakit dan butuh pertolongan." In this case, Lina explained her love for animals and the reason she wanted to become a veterinarian. In the fragment of the conversation above, the answer "Veterinary" can actually answer Udin's question about what Lina's aspirations are. However, Lina's answer to the conversation fragment above indicates that Lina feels it is impolite to just be a veterinarian even though the answer is able to answer Udin's question. The following is a 
discussion of research results regarding the maxims of cooperation that are violated by speakers as a result of ${ }^{155 \mathrm{~s}: 2708-3578 \text { (0ntinine }}$ prioritizing the principle of politeness.

\section{A. The Maxim of Quality}

The maxim of quality requires that each participant in the communication tell the truth. This means that the opposing response should be based on adequate evidence. Thus, based on the data found in the student's book on theme 6 , there are 2 conversational implicatures caused by violating the maxim of quality, namely on pages 97 and 106 the speaker violates the maxim of quality and prioritizes the maxim of generosity on the principle of politeness. Furthermore, in the student book theme 9 conversational implicatures found on page 2 as many as 2 implicatures caused by violations of the maxim of quality based on the principle of cooperation and prioritizing the principle of politeness, namely the maxim of acceptance and the tact maxim in a conversation.

Violation of the maxim of quality also appears on page 28 because the speaker violates the maxim of quality and prioritizes the maxim of acceptance on the principle of politeness. Meanwhile, the implicature found on page $42 \mathrm{~b}$ arises because the speaker prioritizes the tact maxim on the principle of politeness. Therefore, the researcher found 6 conversational implicatures caused by the violation of the maxim of quality in the student books of theme 6 and theme 9 .

\section{B. The Maxim of Quantity}

The maxim of quality expects the speech participant to respond or answer as much as needed by the interlocutor. This study also found several conversational implicatures that occurred as a result of the violation of the maxim of quantity. In theme 6 , the speaker violates the maxim of quantity and prioritizes 2 principles of politeness, namely the tact maxim on pages 6 and 23, while on pages 167-168 the speaker prioritizes the maxim of acceptance. The same thing happened in book theme 9 , the speakers violated the maxim of quantity and prioritized 2 principles of politeness, namely the tact maxim on pages $2 \mathrm{~b}$ and 21 while the maxim of acceptance was found on pages 59 and 65. Therefore, it was found that 8 total conversational implicatures were caused by violation of the maxim of quantity in the student books theme 6 and theme 9.

\section{The Maxim of Relevance}

The maxim of relevance requires each participant to make a relevant contribution to the subject of the conversation. The maxim of relevance emphasizes the relationship between the speech content of the speech participants. However, sometimes the explicit response given does not appear to be relevant to the subject because there is already a common background knowledge between the speaker and the interlocutor so that communication is still ongoing. In other words, it seems explicitly irrelevant but is actually implicitly relevant. Based on this theory, the data were found that speakers violated the maxim of relevance in the student book theme 6 on page 171 and prioritized the principle of politeness, namely the tact maxim. Furthermore, in the student book theme 9 page 42a, the speaker violates the maxim of relevance on the principle of cooperation and prioritizes the maxim of humility on the principle of politeness.

Thus, the violation of the maxim of relevance that gave rise to this conversational implicature was found twice and rarely found in student books in both themes 6 and 9. Based on data found, in the student books above, a descriptive qualitative study conducted by Woil, Burhanudin, and Sinaga (2019) entitled Implicatures in Anecdotal Texts in Indonesian Language Textbooks for Class X SMA also found that there were 18 non-conventional implicature data or conversational implicature. In addition, a previous study using a qualitative descriptive method conducted by Fauzi, Al-Muhamady and Maki (2020) entitled The Phenomenon of Conversational Implicatures in an Animated Film Salahhudin Al Ayyubi based on Grice 


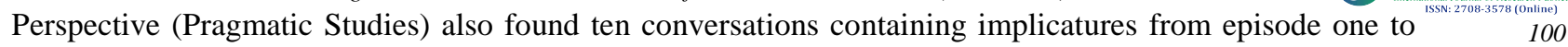
three.

\subsection{The Conventional Implicature}

Conventional implicatures do not have to occur in conversation and do not rely on specific contexts to interpret them. Conventional implicatures are associated with special words and produce additional meanings that are conveyed when those words are used. In other words, conventional implicatures are literal meanings as expressed by formally structural sentence elements. It can be concluded that conventional implicatures explain more about what is meant (Yule, 1996). Moreover, the sample of conventional implicature was then presented bellow which was found in the book theme 6 on page 150 .

"Ingatkah kamu tentang rumah-rumah ibadah di Indonesia? Tentu kamu telah mempelajari bagaimana umat beragama tersebut menggunakannya."

Indonesia has several religions that are believed by its people and of course, each religion has a different way of worshiping in their respective houses of worship. The implication of the sentence above is that the word using it refers to how people based on their respective religions worship. Based on the theory of conventional implicature according to Yule above, the researcher found 11 conventional implicature data contained in the student books of theme 6 and theme 9. The first data in the student book of theme 6 found 4 conventional implicatures. The first implicature is found on page 112, two conventional implicatures are found on page 150 and one other conventional implicature is found on page 167. In addition, the researcher also found 7 other conventional implicatures in the student book theme 9. A first conventional implicature data was found on page 37, three conventional implicatures were found on page 55, one implicature was found on page 91, on page 109 and one other implicature was found on page 147.

Based on the research data on conventional implicatures found in the student books of theme 6 and theme 9 above, there was also a descriptive qualitative study which was conducted by Woil, Burhanudin, and Sinaga (2019) entitled Implicature on Anecdotal Texts in Indonesian High School Class Textbooks. X which also found 2 conventional implicatures. Regarding conventional implicatures, Rahmi and Tressyalina (2020) in a study also found that there were 11 conventional implicatures contained in Abdur's jokes at the Stand Up Comedy event.

\subsection{The Context of Implicatures}

Context is aspects of the physical or social environment that are related to certain utterances. The notion of context is beyond its obvious embodiment such as the physical setting in which an utterance is produced which includes linguistic and social factors (Cummings, 2007). In relation to the context of the speech situation, Wijana (in Haryono 2010) suggests that the context in question includes the following aspects; the speaker and the interlocutor, the context of the speech, the purpose of the speech, the goal as a form of action or activity, speech as a product of verbal acts.

Thus, the context behind the students' books on these two themes was tended to develop according to the theory previously stated. In this case, the context found was in the form of background knowledge that is understood jointly by the speaker and his/her interlocutor. This context played a role in helping the speech partner in interpreting the intent that the speaker wanted to express. Moreover, the background speech context in the students' books was based on the themes proclaimed in each book. In this case, the background context in the student's book theme 6 was about ideals, and theme 9 is the wealth of the Indonesian nation.

Therefore, the background possessed by each speaker in the conversation was in line with the background knowledge possessed by the interlocutor and by the students as readers in understanding the content of the 

overall influenced by the themes proclaimed in each book that must be studied and understood by 4th-grade elementary school students in the learning process. In addition, the context of behavior in communication was also found which were directly and indirectly directed at the interlocutor in the written conversation and the student as the reader.

\section{Conclusion}

Based on the results of research on 4th-grade elementary school students' books theme 6 and theme 9 as discussed in the previous subchapter, it can be concluded that;

1. The implicatures found in the student books of theme 6 and 9 were conventional and non-conventional implicatures. In the student book theme 6 , it was found 7 conversational implicatures and in the student book theme 9 , there were 8 conversational implicatures found. In addition, the researcher also found 4 conventional implicatures in the student book theme 6 , and 8 other conventional implicatures in the student book theme 9 .

2. The deviation from the cooperative principle found in the student book is committed because the speaker prioritizes the politeness principle. The dominant maxim that is violated based on the principle of cooperation is the maxim of quantity which raises 8 conversational implicatures. Meanwhile, the next maxim is the maxim of quality which raises 6 conversational implicatures. Furthermore, the speaker also violates the maxim of relevance which raises 2 conversational implicatures.

3. The context found in the speech events in the student books of theme 6 and theme 9 above is in the form of background knowledge that is mutually understood by the speaker and his interlocutor. This context plays a role in helping the speech partner in interpreting the intent that the speaker wants to express. The speech context behind the student book theme 6 is about ideals and theme 9 is the wealth of the Indonesian nation. Therefore, the background possessed by each speaker in a conversation is in line with the background knowledge possessed by the interlocutor and by the students. The context of the purpose of speech found in theme 6 and theme 9 books is overall influenced by the theme proclaimed in each book. In addition, it was also found that the context of behavior in communication was directly and indirectly directed at the interlocutor in written conversation and the students.

\section{References}

Cummings, L. 2007. Pragmatik sebuah Perspektif Multidisipliner. Pustaka Pelajar.

Dhanawaty, N. M., Satyawati, M. S., \& Widarsini, N. P. N. 2017. Pengantar Linguistik Umum. Pustaka Larasan.

Fauzi, A. I., Al-Muhammady, F. H., \& Maki, A. 2020. Kajian Bahasa, Sastra dan Budaya Arab: Fenomena Implikatur Percakapan dalam Film Animasi Salahudin Al Ayyubi Perspektif Grice (kajian pragmatik). Prosiding Semnasbama, Peran Mahasiswa Bahasa Arab dalam Menghadapi Revolusi Industri 4.0. Universitas Negeri Malang. 392 - 403

Grice, H. P. 1975. Logic and Conversation. Syntax and Semantics, Speech Act. 3th. Academic Press.

Haliko, M. K. 2017. Implikatur Percakapan dalam Talk Show Hitam Putih di Trans 7. Jurnal Bahasa dan Sastra, 2(1): 77-85.

Haryono, S. 2010. Kajian Pragmatik: Seni Pertunjukan Opera Jawa.

Jumanto. 2006. "Komunikasi fatis di kalangan penutur Jati bahasa Inggris". (Desertasi). Depok: Program Pascasarjana Fakultas Ilmu Pengetahuan Budaya, Universitas Indonesia.

Leech, G. 1983. Principles of Pragmatics. Longman.

Nababan, P. W. J. 1987. Ilmu Pragmatik: Teori dan Penerapannya. Depdikbud.

Nugraheni, Y. 2010. Analisis Implikatur pada Naskah Film Harry Potter and the Goblet of Fire. Prosiding Seminar Nasional Unimus. Universitas Muhammadiyah Semarang. 


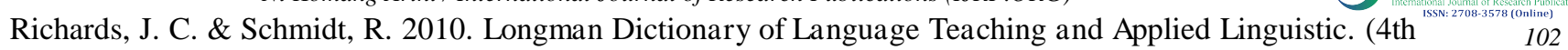
ed.). Pearson Education Limited.

Wijana, I. D. Putu. 1996. Dasar-Dasar Pragmatik. Andi Offset.

Woil, J. P., Burhanudin, D., \& Sinaga, M. 2019. Implikatur pada Teks Anekdot dalam Buku Teks Pelajaran Bahasa Indonesia SMA Kelas X. Jurnal Tuah, 1(1), 34-42.

Yule, G. 1996. Pragmatics. (Indah Fajar Wahyuni). Pustaka Pelajar. 